\title{
Preparation of bioactive interferon alpha-loaded polysaccharide nanoparticles using a new approach of temperature-induced water phasel water-phase emulsion [Retraction]
}

\begin{abstract}
Liu G, Xu D, Jiang M, Yuan W. Preparation of bioactive interferon alpha-loaded polysaccharide nanoparticles using a new approach of temperature-induced water phase/waterphase emulsion. Int J Nanomedicine. 2012;7:4841-4848.
\end{abstract}

The Editor-in-Chief and Publisher of the International Journal of Nanomedicine have been alerted to an unacceptable level of image duplication in the published article.
The affected figures within the article are:

- Figure 1(B) is a duplicate of 1(A).

The authors were contacted and were unable to sufficiently explain the irregularities in the images or satisfactorily provide the original images.
International Journal of Nanomedicine

\section{Publish your work in this journal}

The International Journal of Nanomedicine is an international, peerreviewed journal focusing on the application of nanotechnology in diagnostics, therapeutics, and drug delivery systems throughou the biomedical field. This journal is indexed on PubMed Central, MedLine, CAS, SciSearch ${ }^{\circledR}$, Current Contents ${ }^{\circledR} /$ Clinical Medicine,
Journal Citation Reports/Science Edition, EMBase, Scopus and the Elsevier Bibliographic databases. The manuscript management system is completely online and includes a very quick and fair peer-review system, which is all easy to use. Visit http://www.dovepress.com/ testimonials.php to read real quotes from published authors. 